\title{
HUBUNGAN PAPARAN ASAP ROKOK DENGAN TANDA-TANDA VITAL PADA BALITA DI KABUPATEN PATI
}

\author{
Desi Sariyani ${ }^{1}$, Ana Rofika ${ }^{2}$ \\ ${ }^{1}$ Staff Dosen Program Studi Sarjana Kebidanan STIKes Bakti Utama Pati \\ ${ }^{2}$ Staff Dosen Program Studi Diploma Tiga Kebidanan STIKes Bakti Utama Pati \\ Alamat Korespondensi: deesisariyani12@gmail.com
}

\begin{abstract}
Abstrak
Zat berbahaya yang terkandung dalam asap rokok dapat mengganggu kesehatan balita, apalagi di masa pertumbuhan anak-anak sangat rentan terhadap penyakit karena system kekebalan tubuhnya masih belum sempurna sampai usianya melewati tahun ketujuh. Anak-anak yang terpapar asap rokok sejak usia dini akan meningkatkan risiko penyakit kardiovaskuler (CVD). Tujuan penelitian ini adalah untuk mengetahui hubungan paparan asap rokok dengan tanda-tanda vital pada balita di Kabupaten Pati. Penelitian ini merupakan penelitian jenis correlation dengan design cross sectional. Sampel penelitian ini adalah 184 balita yang salah satu anggota keluarganya merupakan perokok aktif yang masih merokok di dalam rumah dengan teknik probability sampling yaitu stratified random sampling. Analisis yang digunakan dalam penelitian ini adalah cross sectional dengan hasil $\mathrm{p}$-value $<0,05$. Berdasarkan hasil analisis diperoleh ada hubungan paparan asap rokok dengan tanda-tanda vital pada balita dengan hasil p-value yaitu 0,000 $(\mathrm{p}<0,05$. Berdasarkan hasil penelitian, disarankan untuk meningkatkan kesadaran masyarakat agar tidak merokok didalam rumah sehingga dapat menekan angka kesakitan pada balita akibat asap rokok.
\end{abstract}

Kata Kunci: Paparan asap rokok, Tanda-tanda vital, Balita

\begin{abstract}
Hazardous substances contained in cigarette smoke can harm the health of toddlers, especially when they are growing children are very susceptible to disease because their immune systems are still not perfect until they are past the seventh year. Children who are exposed to secondhand smoke from an early age are at increased risk of cardiovascular disease (CVD). The purpose of this study was to determine the relationship between cigarette smoke exposure and vital signs in toddlers in Pati Regency. This research is a type of correlation research with a cross-sectional design. The sample of this study was 184 toddlers whose family members were active smokers who still smoked in the house using a probability sampling technique, namely stratified random sampling. The analysis used in this study was cross-sectional with the resulting p-value $<0.05$. Based on the results of the analysis, it was found that there was a relationship between cigarette smoke exposure and vital signs in toddlers with a p-value of $0.000(\mathrm{p}<0.05$. Based on the results of the study, it is suggested to increase public awareness not to smoke in the house so that it can reduce the morbidity rate in toddlers due to cigarette smoke.
\end{abstract}

Keywords: Cigarette smoke exposure, Vital signs, Toddler 


\section{PENDAHULUAN}

Hak untuk menghirup udara bersih tanpa paparan asap rokok telah menjadi perhatian dunia. World Health Organization (WHO) memprediksi penyakit yang berkaitan dengan rokok akan menjadi masalah kesehatan di dunia (Kemenkes RI, 2013). Hal tersebut disebabkan oleh semakin meningkatnya jumlah perokok di dunia. Jumlah perokok di seluruh dunia kini mencapai 1,2 milyar orang dan 800 juta diantaranya berada di negara berkembang. Indonesia merupakan negara ketiga dengan jumlah perokok terbesar di dunia setelah China dan India $^{19}$. Indonesia menempati urutan pertama di negara ASEAN untuk jumlah perokok anak (Lian \& Dorotheo, 2016)

Rata-rata setiap 5,5 menit terjadi kematian yang disebabkan karena rokok. Perokok aktif memiliki risiko sepuluh kali lipat terkena kanker paru-paru, dua kali lipat terkena risiko infark miokard, dan enam kali lipat terkena risiko penyakit obstruksi paru kronik. Selain itu rokok juga dapat menyebabkan kerugian ekonomi dan peningkatan mordibitas (Roberts, Wagler, \& Carr, 2017). Berdasarkan Riset Kesehatan Dasar (2018) menyebutkan bahwa prevalensi perokok di Indonesia mencapai lebih dari sepertiga penduduk $(36,3 \%)$. Perokok pada usia 10-18 tahun mencapai $8,8 \%$ pada tahun 2016 dan meningkat di tahun 2018 mencapai 9,1\%. Angka tersebut masih jauh dari target pemerintah yaitu sebesar 5,4\% .

Rokok mengandung 4000 zat kimia yang berbahaya bagi kesehatan, seperti Nikotin yang bersifat adiktif dan Tar yang bersifat karsinogenik, bahkan juga Formalin. Dampak negatif akibat rokok tidak hanya dirasakan oleh perokok aktif saja, perokok pasif juga dapat terkena dampak tersebut. Hal tersebut dikarenakan perokok pasif menghirup asap sampingan yang dikeluarkan oleh rokok yang dibakar. Populasi yang sangat rentan terhadap asap rokok adalah anak-anak, karena mereka menghirup udara lebih sering dari pada orang dewasa (Kemenkes RI, 2013)

Jumlah perokok pasif anak-anak di Indonesia sebanyak 43 juta anak, yang 11,4 juta diantaranya baru berusia 0-4 tahun. Anak-anak sangat rawan menjadi perokok pasif karena pernafasan anakanak lebih banyak dibanding orang dewasa sehingga asap rokok dapat terhirup lebih banyak. Ditambah lagi dengan kurangnya kepedulian dan pengetahuan orang tua dan perokok itu sendiri mengenai bahaya asap rokok pada kesehatan anak (Perdana et al, 2014).

Anak-anak disadari atau tidak, sering menghirup asap rokok yang terpapar di udara, baik yang dihembuskan oleh perokok di tempattempat umum atau dari sisa pembakaran di puntung rokok yang tersebar. Berbagai zat berbahaya yang terkandung dalam asap rokok masuk kedalam tubuh anak-anak dan dapat mengganggu kesehatannya, apalagi di masa pertumbuhan anak-anak sangat rentan terhadap penyakit karena sistem kekebalan tubuhnya masih belum sempurna sampai usianya melewati tahun ketujuh (Perdana et al, 2014). Menurut Raghuveer et al (2016) anakanak yang terpapar asap rokok sejak usia dini akan meningkatkan risiko penyakit kardiovaskular (CVD). Penelitian ini menjadi penting karena anak adalah generasi penerus bangsa dan memiliki hak untuk menghirup udara sehat bebas paparan asap rokok.

Tujuan khusus penelitian ini untuk mengetahui gambaran balita yang terpapar asap rokok di Kabupaten Pati dan menganalisis hubungan paparan asap rokok dengan tanda-tanda vital pada balita di Kabupaten Pati 


\section{METODE PENELITIAN}

Penelitian ini merupakan penelitian jenis correlational dengan design cross sectional yang dilakukan di desa lokus masalah pernapasan Kabupaten Pati yang ada di wilayah kerja Puskesmas Sukolilo I, Puskesmas Pati I, Puskesmas Pati II, dan Puskesmas Widarijaksa Kabupaten Pati tahun 2020. Sampel penelitian adalah 184 balita yang tersebar di 4 wilayah kerja puskesmas. Keriteria inklusi penelitian ini adalah responden yang salah satu anggota keluarganya merupakan perokok aktif yang masih merokok di dalam rumah, tidak menderita oenyakit kronis dan cacat bawaan. Kriteria eksklusi adalah anak yang menderita pneumonia, asma, TBC, atau penyakit lain yang tidak memungkinkan menjadi responden.
Pengumpulan data dilakukan dengan melakukan survey banyaknya konsumsi rokok yang dilakukan oleh anggota keluarga dalam satu hari dan melakukan penilaian tanda-tanda vital pada balita yang meliputi tekanan darah, nadi, pernapasan, dan suhu. Data yang terkumpul kemudian ditabulasi ke dalam matriks pengumpulan data yang telah dibuat sebelumnya oleh peneliti dan kemudian dilakukan analisa data.

Uji korelasi yang digunakan dalam penelitian ini yaitu Chi-Square. Penelitian ini telah mendapatkan surat keterangan laik etik dari Komisi Etik Penelitian Universitas 'Aisyiyah Yogyakarta

\section{HASIL PENELITIAN}

Tabel 1 .

Gambaran Paparan asap rokok pada balita

\begin{tabular}{c|c|c}
\hline Paparan asap rokok (per hari) & n & \% \\
\hline$<5$ batang rokok & 66 & 35,9 \\
$5-10$ batang rokok & 78 & 42,4 \\
$>10$ batang rokok & 40 & 21,7 \\
\hline Total & $\mathbf{1 8 4}$ & $\mathbf{1 0 0 \%}$ \\
\hline
\end{tabular}

Tabel 1 menunjukkan gambaran paparan asap rokok pada balita diperoleh hasil bahwa balita terpapar asap rokok sebanyak 5-10 batang rokok per hari sebesar 78 responden $(42,4 \%)$, dan terdapat 40 responden $(21,7 \%)$ terpapar asap rokok sebanyak $>10$ batang rokok per harinya.

Tabel 2.

Gambaran tanda-tanda vital pada balita

\begin{tabular}{|c|c|c|c|}
\hline & Tanda-tanda vital & Jumlah & Persentase $(\%)$ \\
\hline \multicolumn{4}{|c|}{ Tekanan darah } \\
\hline a. & $\begin{array}{l}\text { Rendah (sistol }<95-110 \mathrm{mmHg} \text { dan diastolic } \\
<55-70 \mathrm{mmHg} \text { ) }\end{array}$ & 27 & 14,7 \\
\hline b. & $\begin{array}{l}\text { Normal (sistol } 95-110 \mathrm{mmHg} \text { dan diastolic } \\
55-70 \mathrm{mmHg} \text { ) }\end{array}$ & 91 & 49,5 \\
\hline \multirow[t]{2}{*}{ c. } & $\begin{array}{l}\text { Tinggi }(\text { sistol }>95-110 \mathrm{mmHg} \text { dan diastolic } \\
>55-70 \mathrm{mmHg}\end{array}$ & 66 & 35,9 \\
\hline & Total & 184 & 100 \\
\hline \multicolumn{4}{|c|}{ Nadi (kali/menit) } \\
\hline a. & Rendah $(<80-90)$ & 31 & 16,8 \\
\hline & Normal (80-90) & 85 & 46,2 \\
\hline & Tinggi (>80-90) & 68 & 37,0 \\
\hline \multicolumn{2}{|r|}{ Total } & 184 & 100 \\
\hline
\end{tabular}




\begin{tabular}{llcc}
\hline \multicolumn{2}{l}{ Pernapasan (kali/menit) } & & \\
a. & Rendah $(<20-30)$ & 35 & 19,0 \\
b. & Normal $(20-30)$ & 85 & 46,2 \\
c. & Tinggi $(>20-30)$ & 64 & 34,8 \\
\hline \multicolumn{1}{c}{ Total } & $\mathbf{1 8 4}$ & $\mathbf{1 0 0}$ \\
\hline \multicolumn{2}{r}{ Suhu } \\
a. Hipotermi $\left(<36,3-37,7^{\circ} \mathrm{C}\right)$ & 12 & 6,5 \\
b. & Normal $\left(36,3-37,7^{\circ} \mathrm{C}\right.$ & 169 & 91,8 \\
c. & Hipertermi $\left(>36,3-37,7^{\circ} \mathrm{C}\right)$ & 3 & 1,6 \\
\hline \multicolumn{2}{r}{ Total } & $\mathbf{1 8 4}$ & $\mathbf{1 0 0}$ \\
\hline
\end{tabular}

Tabel 2 menunjukkan gambaran tanda-tanda vital pada balita. Sebagian besar tekanan darah balita normal yaitu
$49,5 \%$, nadi balita normal yaitu $46,2 \%$, pernapasan balita normal $46,2 \%$, dan suhu balita normal 91,8\%.

Tabel 3. Hasil Analisis Chi-Square

\begin{tabular}{|c|c|c|c|c|c|c|c|c|c|}
\hline \multirow{3}{*}{ PAR (per hari) } & \multicolumn{6}{|c|}{ Tekanan Darah } & \multirow{2}{*}{\multicolumn{2}{|c|}{ Total }} & \multirow{2}{*}{ p-value } \\
\hline & \multicolumn{2}{|c|}{ Rendah } & \multicolumn{2}{|c|}{ Normal } & \multicolumn{2}{|c|}{ Tinggi } & & & \\
\hline & $\mathrm{n}$ & $\%$ & $\mathrm{n}$ & $\%$ & $\mathrm{n}$ & $\%$ & $\mathrm{n}$ & $\%$ & \\
\hline$<5$ batang & 4 & 6,1 & 59 & 89,4 & 3 & 4,5 & 66 & 100 & \\
\hline $5-10$ batang & 18 & 23,1 & 26 & 33,3 & 34 & 43,6 & 78 & 100 & 0,000 \\
\hline$>10$ batang & 5 & 12,5 & 6 & 15,0 & 29 & 72,5 & 40 & 100 & \\
\hline Total & 27 & 14,7 & 91 & 49,5 & 66 & 35,9 & 184 & 100 & \\
\hline \multirow{3}{*}{ PAR (per hari) } & \multicolumn{6}{|c|}{ Nadi } & \multirow{2}{*}{\multicolumn{2}{|c|}{ Total }} & \\
\hline & \multicolumn{2}{|c|}{ Rendah } & \multicolumn{2}{|c|}{ Normal } & \multicolumn{2}{|c|}{ Tinggi } & & & p-value \\
\hline & $\mathrm{n}$ & $\%$ & $\mathrm{n}$ & $\%$ & $\mathrm{n}$ & $\%$ & $\mathrm{n}$ & $\%$ & \multirow{5}{*}{0,000} \\
\hline$<5$ batang & 2 & 3,0 & 63 & 95,5 & 1 & 1,5 & 66 & 100 & \\
\hline $5-10$ batang & 24 & 30,8 & 22 & 28,2 & 32 & 41,0 & 78 & 100 & \\
\hline$>10$ batang & 5 & 12,5 & 0 & 0,0 & 35 & 87,5 & 40 & 100 & \\
\hline Total & 31 & 16,8 & 85 & 46,2 & 68 & 37,0 & 184 & 100 & \\
\hline \multirow[t]{3}{*}{ PAR (per hari) } & \multicolumn{6}{|c|}{ Pernapasan } & \multirow{2}{*}{\multicolumn{2}{|c|}{ Total }} & n nolu \\
\hline & & & & & & & & & p-value \\
\hline & $\mathrm{n}$ & $\%$ & $\mathrm{n}$ & $\%$ & $\mathrm{n}$ & $\%$ & $\mathrm{n}$ & $\%$ & \\
\hline$<5$ batang & 3 & 4,5 & 63 & 95,5 & 0 & 0,0 & 66 & 100 & \\
\hline $5-10$ batang & 25 & 32,1 & 20 & 25,6 & 33 & 42,3 & 78 & 100 & 0,000 \\
\hline$>10$ batang & 7 & 17,5 & 2 & 5,0 & 31 & 77,5 & 40 & 100 & \\
\hline Total & 35 & 19,0 & 85 & 46,2 & 64 & 34,8 & 184 & 100 & \\
\hline \multirow[t]{3}{*}{ PAR (per hari) } & \multicolumn{6}{|c|}{ Suhu } & \multirow{2}{*}{\multicolumn{2}{|c|}{ Total }} & \\
\hline & \multicolumn{2}{|c|}{ hipotermi } & \multicolumn{2}{|c|}{ normal } & \multicolumn{2}{|c|}{ hipetermi } & & & p-value \\
\hline & $\mathrm{n}$ & $\%$ & $\mathrm{n}$ & $\%$ & $\mathrm{n}$ & $\%$ & $\mathrm{n}$ & $\%$ & \multirow{5}{*}{0,000} \\
\hline$<5$ batang & 0 & 0,0 & 66 & 100 & 0 & 0,0 & 66 & 100 & \\
\hline $5-10$ batang & 3 & 3,8 & 75 & 96,2 & 0 & 0,0 & 78 & 100 & \\
\hline$>10$ batang & 9 & 22,5 & 28 & 70,0 & 3 & 7,5 & 40 & 100 & \\
\hline Total & 12 & 6,5 & 169 & 91,8 & 3 & 1,6 & 184 & 100 & \\
\hline
\end{tabular}

Tabel 3 menunjukkan hubungan yang signifikan antara tanda-tanda vital pada balita dengan paparan asap rokok dimana pada tekanan darah diperoleh $\mathrm{p}$ - value $=0,000<0,05$ yang artinya adanya hubungan antara paparan asap rokok dengan tekanan darah balita, pada nadi diperoleh $\mathrm{p}$-value $=0,000<0,05$ yang 
artinya adanya hubungan antara paparan asap rokok dengan nadi pada balita, pada pernapasan diperoleh $\mathrm{p}$-value $=0,000<$ 0,05 yang artinya adanya hubungan antara paparan asap rokok dengan pernapasan pada balit, dan pada suhu diperoleh $\mathrm{p}$-value $=0,000<0,05$ yang artinya adanya hubungan paparan asap rokok dengan suhu pada balita.

\section{PEMBAHASAN}

Responden dalam penelitian ini adalah balita dengan usia 2-5 tahun di beberapa desa yang berada di Wilayah Kerja Puskesmas Pati I, Puskesmas Juwana, Puskesmas Batangan, dan Puskesmas Sukolilo dan di dalam ruamahnya terdapat anggota keluarga sebagai perokok aktif. Berdasarkan hasil penelitian yang telah dilakukan uji analisis menggunakan uji chi-square pada table 3 tentang hubungan paparan asap rokok (PAR) dengan tanda-tanda vital pada balita diperoleh hasil bahwa PAR terdapat hubungan dengan variable tekanan darah, nadi, pernapasa, dan suhu.

Hasil penelitian ini sejalan dengan penelitian yang dilakukan oleh Seyedzadeh, Hashemi \& Soleimani yang menyimpulkan bahwa paparan asap rokok dapat menyebabkan peningkatan pada tekanan darah sistolik dan diastolic. Perokok pasif dikaitkan dengan kerusakan endotel pada anak-anak sehingga dapat menyebabkan kerukan dini pada arteri (Celermajer, et $a l$ ). Dampak asap rokok berpengaruh pada pembuluh darah perifer melalui zat yang terkandung didalam rokok (karbonmonoksida, benzopirena/ ammonia, dan zat karsinogenik) sehingga mengakibatkan risiko penyakit kardiovaskular. Hasil penelitian ini juga sejalan dengan penelitian yang dilakukan oleh Simonetti, et al yang menyebutkan bahwa kenaikan tekanan darah pada anak-anak $\pm 1,2 \mathrm{mmHg}$ dan kenaikan tekanan darah lebih tinggi pada anak dengan orang tua yang merokok.

Paparan asap rokok baik yang diterima oleh perokok aktif maupun perokok pasif dapat menimbulkan berbagai macam gangguan kesehatan, salah satunya yaitu peningkatan tekanan darah atau yang lebih sering dikenal dengan istilah hipertensi. Beberapa penelitian telah menyebutkan bahwa seseorang yang merokok kronis atau dalam jangka waktu yang lama menunjukkan terjadinya peningkatan tekanan darah. Peningkatan tekanan darah tersebut berhubungan dengan efek racun yang dihasilkan dari asap rokok yaitu berupa nikotin dan karbonmonoksida (CO). Pada perokok pasif peningkatan tekanan darah tergantung pada lama dan jenis paparan asap rokok yang diterima dari lingkungan (Aurelio, 2010).

Paparan asap rokok yang diterima oleh seorang perokok pasif berhubungan dengan peningkatan terjadinya atherosklerosis, penyakit pembuluh darah dan stroke. Mekanisme yang mungkin terjadi akibat efek sebagai perokok pasif adalah gangguan pada pembuluh darah arteri. Dimana pembuluh darah arteri berperan penting dalam pengaturan terjadinya gangguan terhadap penyakit kardiovaskuler . Asap rokok yang terhirup ke dalam tubuh baik pada perokok pasif maupun pada perokok aktif dapat menyebabkan terjadinya hipertensi akibat zat-zat kimia yang terkandung di dalam tembakau yang dibakar karena dapat merusak lapisan dalam dinding arteri, sehingga arteri lebih rentan terjadi penumpukan plak (arterosklerosis). Hal ini disebabkan oleh nikotin yang dapat merangsang saraf simpatis sehingga memacu kerja jantung lebih keras dan peran serta karbonmonoksida yang dapat menggantikan oksigen di dalam darah dan memaksa jantung memenuhi 
kebutuhan oksigen tubuh (Setyananda, dkk., 2015).

Berdasarkan hasil penelitian juga diperoleh hasil bahwa paparan asap rokok dapat mengakibatkan perubahan denyut jantung. Hasil penelitian ini sesuai dengan penelitian yang telah dilakukan oleh Barnoya dan Glantz yang menyebutkan bahwa paparan asap rokok dapat menyebabkan perubahan denyut jantung yang tercermin dalam variasi interval RR di EKG yang memberikan informasi tentang kecenderungan terhadap aritmia ventrikel ganas dan kematian jantung. Dua jam terpapar asap rokok dapat mengakibatkan penurunan variabilitas denyut jantung sebanyak $12 \%$. Penurunan detak jantung disebabkan oleh karena zat yang terkandung dalam asap rokok dan memberikan hubungan mekanistik dan menyebabkan takiaritmia.

Penelitian juga menilai keterkaitan antara paparan asap rokok dengan pernapasan pada balita dan diperoleh hasil bahwa paparan asap rokok memiliki hubungan dengan pernapasan pada balita. Melalui uji statistic diperoleh hasil bahwa nilai $\mathrm{p}=0,000<0,05$. Sejalan dengan penelitian yang diakukan oleh Cook dan Strachan, dalam penelitiannya diperoleh hasil bahwa asap rokok menyebabkan terjadinya gangguan pada system pernapasan. Di saluran udara besar ada hipertrofi dan hiperplasia kelenjar mukosa. Perubahan ini diikuti dengan peningkatan produksi lendir yang menyebabkan peningkatan produksi batuk dan dahak. Perubahan struktural pada saluran udara yang lebih kecil berkisar dari peradangan yang relatif ringan hingga penyempitan dan penutupan saluran udara karena peradangan, hiperplasia sel goblet, dan lendir intraluminal. Perubahan parenkim termasuk peningkatan jumlah sel inflamasi dan akhirnya kerusakan dinding alveolar, paling sering di bagian tengah lobulus, yaitu perkembangan emfisema sentrilobular.

Menurut Deborah et all (2010) paparan asap rokok menyebabkan anakanak yang sudah menderita asma mengalami serangan yang lebih berat. Paparan asap rokok pasif menyebabkan gejala pernapasan terganggu, termasuk batuk, dahak, mengi, dan sesak napas, di antara anak-anak usia sekolah. Anakanak yang terpapar asap rokok memiliki risiko yang lebih tinggi mengalami infeksi telinga. Asap rokok dapat menyebabkan terjadinya pneumonia pada balita. Pneumonia adalah peradangan paru dimana asinus terisi dengan cairan radang dengan atau tanpa disertai infiltrasi dari sel radang ke dalam dinding alveoli dan rongga interstisium yang ditandai dengan batuk disertai nafas cepat dan atau nafas sesak pada anak usia balita (Ridha, 2014; Pudiastuti, 2011).

Rokok memiliki efektivitas yang sangat tinggi dalam menyebarkan bahan kimia beracun. Jika diisap di dalam rumah, maka seluruh rumah akan penuh dengan zat beracun, seperti nikotin, karbon monoksida, dan zat pemicu kanker (karsinogen).

Penelitian ini sejalan dengan penelitian yang dilakukan oleh Riyanto dan Kusumawati (2016) dimana dalam penelitiannya diperoleh hasil bahwa asap rokok berpengaruh terhadap infeksi saluran pernapasan akut (ISPA) dengan p-value $=\quad 0,007<\quad 0,05 . \quad$ Rokok merupakan benda beracun yang memberi efek yang sangat membahayakan pada perokok aktif ataupun perokok pasif, terutama pada balita yang tidak sengaja terkontak asap rokok. Nikotin dengan ribuan bahaya beracun asap rokok lainnya masuk ke saluran pernapasan bayi yang dapat menyebabkan Infeksi pada saluran 
pernapasan. Paparan asap rokok berpengaruh terhadap kejadian ISPA pada balita, dimana balita yang terpapar asap rokok berisiko lebih besar untuk terkena ISPA dibanding balita yang tidak terpapar asap rokok.

Sedangkan pada suhu tubuh, berdasarkan hasil penelitian diperoleh bahwa paparan asap rokok berpengaruh terhadap perubahan suhu tubuh. Hal ini sejalan dengan penelitian yang dilakukan oleh Pelissier, et al ditemukan bahwa asap rokok dapat menyebabkan gangguan melalui mekanisme dopaminergic.

\section{KESIMPULAN DAN SARAN}

Sebagian besar responden terpapar asap rokok 5-10 batang per hari. Sebagian besar responden memiliki tanda-tanda vital yang normal. Paparan asap rokok memiliki hubungan dengan tanda-tanda vital pada balita.

Penelitian ini memiliki keterbatasan sehingga peneliti selanjutnya disarankan untuk meneliti factor lain yang mempengaruhi tandatanda vital pada balita seperti riwayat penyakit akut yang diderita oleh anggota keluarga, status gizi, asupan gizi maupun kebiasaan ayah yang tidak cuci tangan setelah merokok. Petugas kesehatan disarankan untuk melakukan pembinaan secara langsung melalui kunjungan rumah kepada masyarakat yang masih merokok didalam rumah maupun merokok didekat bayi, balita, dan anak usia Sekolah Dasar (SD).

\section{DAFTAR PUSTAKA}

Ana et all. 2014. Effect of Tobacco Smoke Exposure During Pregnancy and Preschool Age on Growth from Birth to adolescence: a cohort study

Ash Research Report. Secondhand smoke: The Impact on children. Dalam www.ash.org.uk 2014

Aurelio, L., 2010. Review Article: Does Smoking Act as a Friend or Enemy of Blood Pressure? Let Release Pandora's
Box. SAGE-Hindawi Acces to Research Cardiology Research and Practice, Volume 2011

Barnoya, J., \& Glantz, S. A. (2005). Cardiovascular effects of secondhand smoke: Nearly as large as smoking. Circulation, 111(20), 2684-2698. https://doi.org/10.1161/CIRCULATION AHA.104.492215

Bissoli, M.D.F. 2014. Development of children's personality: The role of early childhood education. Psicologia em Estudo, Maringá, v. 19, n. 4 pp. 587-597

Celermajer D, Adams M, Clarkson P, et al. Passive smoking and impaired endothelium- dependent arterial dilatation in healthy young adults. $\mathrm{N}$ England J Med 1996;334(3):150-4.

Cook, D. G., \& Strachan, D. P. (n.d.). Effects of maternal and paternal smoking on children 's respiratory health. 1998, (0). Retrieved from https://www.ncbi.nlm.nih.gov/pmc/artic les/PMC1447768/pdf/0930482.pdf

Deborah R., Moss, M.D., Lorrie A. Lucht,., Kevin E. Kip \& Steven E. Reis. 2010. Acute physiologic effects of secondhand smoke exposure in children. Nicotine \& Tobacco Research, Volume 12, Number 7 doi: 10.1093/ntr/ntq069. https://www.ncbi.nlm.nih.gov/pubmed/2 0447934

Elizabeth Mumford., David T. Levy and Eduardo Romano. 2005. The Relationship Of Smoking Cessation To Sociodemographic Characteristics, Smoking Intensity, And Tobacco Control Policies. Nicotine \& Tobacco Research Volume 7, Number 3. DOI: 10.1080/14622200500125443.

Febry, A. 2013. Ilmu gizi untuk praktisi kesehatan. Yogyakarta: Graha ilmu

G. Banderali, A. Martelli, M. Landi, F. Moretti, F. Betti, G. Radaelli, C. Lassandro and E. Verduci, 2015. Short and long term health effects of parental tobacco smoking during pregnancy and lactation: a descriptive review. https://www.ncbi.nlm.nih.gov/pmc/artic les/PMC4608184/. Published online 2015 Oct 15. doi: 10.1186/s12967-0150690-y

IOM (Institute of Medicine). 2010. Secondhand Smoke Exposure and Cardiovascular Effects: Making Sense of the Evidence. Washington, DC: The National Academies Press 
Kemenkes RI. 2013. Perilaku Merokok Masyarakat Indonesia. www.depkes.go.id/download.php?file $=d$ ownload/pusdatin/...pdf.

. 2018. Laporan Riset Kesehatan Dasar, $2018 . \quad$ Jakarta. www.depkes.go.id/resources/download/ general/Hasil\%20Riskesdas\%202013.pd f.

. 2018. Profil Kesehatan Indonesia $2018 . \quad$ Jakarta. www.depkes.go.id/.../profil-kesehatanindonesia/Profil-Kesehatan-Indonesia2018.pdf.

Lian, T. Y., and Dorotheo, U., 2016. The Tobacco Control Atlas ASEAN Region, Third Ed, Thailand : SEATCA

Mahmud, A., \& Feely, J. 2004. Effects of passive smoking on blood pressure and aortic pressure waveform in healthy young adults-influence of gender. British Journal of Clinical Pharmacology, 57,3743

Muaris, H. 2006. Lauk bergizi untuk anak balita. Jakarta: Gramedia Pustaka Utama

Muraro et al. 2014. Effect of Tobacco Smoke Exposure During Pregnancy and Preschool Age on Growth from Birth to adolescence: a cohort study. BMC Pediatrics, $\quad 14: 99$ http://www.biomedcentral.com/14712431/14/99.

Perdana, Dhewangga A., dan Agung Eko Budi. (2014). Kampanye Pencegahan Perokok Pasif Pada Anak-anak. FSRD ITB

Raghuveer, G., White, D. A., Hayman, L. L., Woo, J. G., Villafane, J., Celermajer, D., ... Zachariah, J. (2016). Cardiovascular Consequences of Childhood Secondhand Tobacco Smoke Exposure: Prevailing Evidence, Burden, and Racial and Socioeconomic Disparities: A Scientific Statement From the American Heart Association. Circulation, 134(16), e336- e359.doi:10.1161/cir.000000000000044 3

Roberts, C., Wagler, G., \& Carr, M. M. (2017). Environmental Tobacco Smoke: Public Perception of Risks of Exposing Children to Second- and Third-Hand Tobacco Smoke. Journal of Pediatric Health Care, 31(1), e7-e13. doi:10.1016/j.pedhc.2016.08.008

Setyananda, Y. O., Sulastri, D., \& Lestari, Y., 2015. Hubungan Merokok dengan Kejadian Hipertensi pada Laki-laki Usia 35-65 Tahun di Kota Padang. Jurnal Kesehatan Andalas 4(2)

Pelissier, A. L., Attolini, L., Gantenbein, M., \& Bruguerolle, B. (1998). Tobacco smoke influence on heart rate, body temperature, and locomotor activity daily rhythms as assessed by radiotelemetry in rats. Journal of Pharmacological and Toxicological Methods, 38(4), 195-200. https://doi.org/10.1016/S10568719(97)00102-0

Seyedzadeh, A., Hashemi, F., \& Soleimani, A. (2012). Relationship between blood pressure and passive smoking in elementary school children. Iranian Journal of Pediatrics, 22(3), 351-356.

Simonetti GS, Schwertz R, Klett M, et al. Passive smoking increases blood pressure in preschool child. Pediatr Nephrol 2009;24(4):888. (Abstract of Pediatric Nephrology Spring Meeting 2009)

WHO. 2014. Global Youth Tobacco Survey (GYTS): Indonesia Report, 2014. New Delhi: WHO-SEARO, 2015. World Health Organization, Regional Office For South-East Asia.ISBN978-92-9022487-7.

http://www.searo.who.int/tobacco/docu ments/ino_gyts_report_2014.pdf. 